\title{
Antimicrobial Property of Extracts of Indian Lichen against Human Pathogenic Bacteria
}

\author{
Priya Srivastava, ${ }^{1}$ D. K. Upreti, ${ }^{1}$ T. N. Dhole, ${ }^{2}$ \\ Apurva K. Srivastava, ${ }^{3}$ and Meghanand T. Nayak ${ }^{4}$ \\ ${ }^{1}$ Lichenology Laboratory, National Botanical Research Institute (CSIR), Rana Pratap Marg, Lucknow 226001, India \\ ${ }^{2}$ Department of Microbiology, Sanjay Gandhi Post Graduate Institute of Medical Sciences, Lucknow 226014, India \\ ${ }^{3}$ Department of Pathology \& Microbiology, Saraswati Dental \& Medical College, Lucknow 227105, India \\ ${ }^{4}$ Department of Oral and Maxillofacial Pathology, Vyas Dental College and Hospital, Pali Road, Jodhpur, Rajasthan 342005, India
}

Correspondence should be addressed to Priya Srivastava; priya.srivastava84@gmail.com

Received 25 February 2013; Revised 23 July 2013; Accepted 25 July 2013

Academic Editor: Dino Vaira

Copyright (c) 2013 Priya Srivastava et al. This is an open access article distributed under the Creative Commons Attribution License, which permits unrestricted use, distribution, and reproduction in any medium, provided the original work is properly cited.

\begin{abstract}
Context. Usnea ghattensis G. Awasthi (Usneaceae) endemic fruticose lichen found growing luxuriantly in Northern Western Ghats of India, it also contains Usnic acid as a major chemical and tested against some human pathogenic bacteria. Objective. To explore antimicrobial properties of Usnea ghattensis against some human pathogenic bacteria. Materials and Methods. The lichen was extracted in acetone, methanol, and ethanol. In vitro antimicrobial activity was tested initially by Kirby-Bauer technique of disc diffusion method and was confirmed by minimum inhibitory concentration using Broth microdilution method according to the NCCLS guidelines. Results. Ethanol extract was most effective against Bacillus cereus and Pseudomonas aeruginosa with a zone of inhibition $29.8 \pm 0.6 \mathrm{~mm}$ and $12.3 \pm 0.5 \mathrm{~mm}$ diameters at a concentration of $0.2 \mathrm{mg} / \mathrm{mL}$. Acetone and methanol extract demonstrated almost similar activity against Staphylococcus aureus and the zone of inhibition was $24.6 \pm 0.5$ and $24.7 \pm 0.4 \mathrm{~mm}$. Only methanol extract was showing activity against Streptococcus faecalis with a $13.5 \pm 0.8 \mathrm{~mm}$ zone. MIC value noted against Staphylococcus aureus and Streptococcus faecalis was $6.25 \mu \mathrm{g} / \mathrm{mL}$ and $25 \mu \mathrm{g} / \mathrm{mL}$, whereas against Bacillus cereus and Pseudomonas aeruginosa, MIC calculated was $3.125 \mu \mathrm{g} / \mathrm{mL}$ and $200 \mu \mathrm{g} / \mathrm{mL}$, respectively. Conclusion. The present study demonstrates the relatively higher activity of this lichen against not only gram (+) but significantly also against gram (-) bacteria. This indicates that this lichen might be a rich source of effective antimicrobial agents.
\end{abstract}

\section{Introduction}

Medicinal plants are well-known natural sources for the treatment of various diseases since ancient times. Lichens are among the most fascinating organisms on this planet. Lichen is not a single organism the way most other living things are, but rather it is a combination of two organisms which live together intimately. The fungus forms a thallus or lichenized stroma that may contain characteristic secondary metabolites in all lichens [1]. Lichens are valuable plant resources and are used as medicines, food, fodder, dyes perfume, spice, and for miscellaneous purposes. The lichen flora is rather poor in the vicinity of industrial areas and big cities [2], as lichens are very sensitive to various air pollutions. Thus, these organisms are used as air pollution monitors [3]. The specific, even extreme, conditions of their existence, slow growth, and long duration (maximum lifetime spans to several thousand years) are consistent with their abundance in protective metabolites against different physical and biological influences [4]. Lichens have been used for medicinal purposes throughout the ages, such as Cetraria islandica (L.) Ach. (Parmeliaceae), Lobaria pulmonaria (Schreb.) Hoffm. (Lobariaceae) were reported to be effective in the treatment of pulmonary tuberculosis [5].

The use of lichens in medicine is based on the fact that they contain unique and varied biologically active substances, mainly with antimicrobial actions. Because of marked antimicrobial activity of secondary metabolites, lichens, macrofungi, and vascular plants attract great attention of investigators as new significant sources of bioactive substances [69]. The intensive use of antibiotics has selected for antibiotic 
resistance factors and facilitated the spread of multiply resistant microorganisms. Lichen metabolites exert a wide variety of biological actions including antibiotic, antimycotic, antiviral, anti-inflammatory, analgesic, antipyretic, antiproliferative, and cytotoxic effects [10-15]. Although about $8 \%$ of the terrestrial ecosystem consists of lichens and more than 20,000 lichen species are distributed throughout the world, their biological activities and biologically active compounds remain unexplored to a great extent [16].

Usnea ghattensis is an endemic fruticose lichen that grows on different trees and shrubs in Northern Western Ghats of India. Most of the lichen species of the genus Usnea containing Usnic acid as the major chemical constituent are used traditionally in upper respiratory infections, and applied on the skin to treat surface infections or external ulcers. Usnic acid has been used as a human papillomavirus (HPV) treatment and as an oral hygiene agent, with limited effectiveness. In accordance with these facts, in this study, the antimicrobial activity of acetone, methanol, and ethanol extracts of Usnea ghattensis was investigated in vitro in relation to test microorganisms, where some of them promote diseases in humans, animals, and plants and even produce toxins and provoke food deterioration.

\section{Material and Methods}

2.1. Microorganisms. Total six bacteria, three gram positive (Staphylococcus aureus (ATCC 25923), Streptococcus faecalis (ATCC 33186), and Bacillus cereus (ATCC 14579)) and three gram negative (Escherichia coli (ATCC 25922), Pseudomonas aeruginosa (ATCC 29853), and Salmonella typhimurium (ATCC 13311)), were used to assess the antimicrobial properties of the test samples. These Bacteria were kept on nutrient agar plates at $4^{\circ} \mathrm{C}$, respectively. For use in experiments, the organisms were subcultured in blood agar culture medium and MacConkey's medium.

2.2. Lichen Material. The plant material of Usnea ghattensis was collected during Dec. 2009 from Lingmala Forest area, Mahabaleshwar, Satara district, Maharashtra, the northern western Ghat area of India between altitudes of 1200 and $1340 \mathrm{~m}$. One voucher specimen was preserved in the herbarium of National Botanical Research Institute, Lucknow (LWG).

2.2.1. Extraction of Lichen Material. The lichen samples were washed to remove debris; the air was dried, pulverized to powder, and stored in a sterile glass bottle in the refrigerator. $10 \mathrm{~g}$ portions of sieved powder was added to $100 \mathrm{~mL}$ of solvents (acetone, ethanol, and methanol) and left for three days at room temperature. The crude extract was prepared by decanting, followed by filtration through muslin cloth, and further filtered with Whatman No. 1 filter paper to obtain a clear filtrate. The filtrates were further purified by membrane filter using $0.45 \mu \mathrm{m}$ pore size filters. The extracts were then evaporated to dryness under reduced pressure and redissolved in respective solvents to attain the required concentrations of $0.1 \mathrm{mg} / \mathrm{mL}$ and $0.2 \mathrm{mg} / \mathrm{mL}$ for antibacterial screening. These extracts were kept at $4^{\circ} \mathrm{C}$ till used.
2.3. Preparation of Antibiotic Disc. Individual crude extracts were dissolved in respective solvents. Two different concentrations of extracts, that is, $0.1 \mathrm{mg} / \mathrm{mL}$ and $0.2 \mathrm{mg} / \mathrm{mL}$, were used for preparing disc. Whatman filter paper disc with diameter of $6 \mathrm{~mm}$ was used for preparing discs. Each disc was impregnated with $10 \mu \mathrm{L}$ of lichen's crude extract, allowing the solvent to evaporate between the applications and leaving the lichen extract on discs without the solvent. These freshly prepared discs were used for the determination of antibacterial activity.

2.4. Determination of Antimicrobial Activity. Antimicrobial susceptibility test of the selected pathogens was done by Disc diffusion method using Kirby-Baeur technique [17] and as per recommendation of NCCLS [18]. All the tests were performed on Mueller Hinton agar plates. Suspension of microbial cultures ( $0.5 \mathrm{McF}$ arlands) was inoculated on the entire surface of the Mueller Hinton agar media in a Petri plate using sterile swab sticks. The sterile discs of diameter $6 \mathrm{~mm}$ were impregnated with lichen extract solutions $(0.1 \mathrm{mg} / \mathrm{mL}$ and $0.2 \mathrm{mg} / \mathrm{mL}$ ) and placed onto the cultured Mueller Hinton agar plates. Inoculated plates were incubated at $37^{\circ} \mathrm{C}$ for 24 hrs.

On the second day, plates were read by taking measurement of zone of inhibition around each disc. The diameter of zone of inhibition of bacteria was recorded in millimeters. Pure acetone, methanol, and ethanol were taken as negative control as in accordance with Sati and Joshi, 2011 [19], whereas commercial Gentamicin and Ceftriaxone were used as positive control as in accordance with Owolabi et al., 2007 [20]. Gentamicin was taken as positive control for gram positive bacteria and Ceftriaxone was used for gram-negative bacteria. The assay was done in triplicates and checked with the control plate. To determine the affectivity of lichen crude extracts at different volumes, two different concentrations of lichen crude extracts were taken on each paper disc, on every Petri plate.

2.5. Minimum Inhibitory Concentration. The minimal inhibitory concentration (MIC) of the crude extract was determined by microdilution techniques in Mueller Hinton Broth (MHB), according to National Committee for Clinical Laboratory Standard, USA Guidelines [21]. A series of two fold dilutions with concentrations ranging from $100 \mu \mathrm{g} / \mathrm{mL}$ to $0.195 \mu \mathrm{g} / \mathrm{mL}$ for methanol extract was used in the experiment against $S$. aureus, S. faecalis, and B. cereus. For P. aeruginosa, no dilutions were done because no activity was recorded below $200 \mu \mathrm{g} / \mathrm{mL}$. Twofold dilutions of extracts and components were prepared in Mueller Hinton broth (MHB) for bacterial cultures. The inoculates were prepared in the same medium at a density adjusted to a $0.5 \mathrm{McF}$ arland turbidity standard colony forming units, and diluted 1:10 for the broth microdilution procedure. Then, $100 \mu \mathrm{L}$ of diluted extracts and $100 \mu \mathrm{L}$ of bacterial suspensions were dispensed in 96 well sterile microtiter plate. The microtiter plates were incubated at $37^{\circ} \mathrm{C}$ and $\mathrm{MIC}$ was determined after $24 \mathrm{~h}$ of incubation. The MIC was determined by establishing visible growth of the microorganisms. The boundary dilution without any visible growth was defined as the MIC for the tested microorganism 


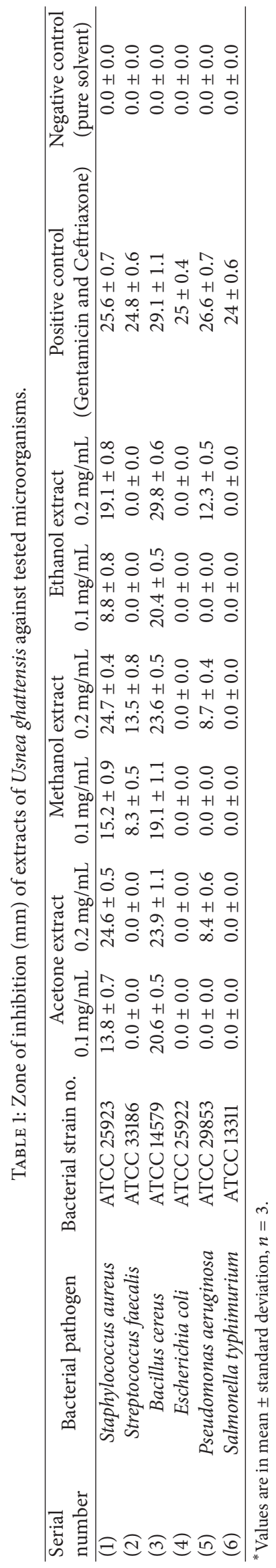


at the given concentration. Untreated bacteria were taken as positive control and $\mathrm{MHB}$ was taken as negative control. All experiments were performed in triplicate.

2.6. Interpretation of Results. The results of disc diffusion assay are expressed as mean $\pm \mathrm{SD}$ of three replicates in each test.

\section{Results}

3.1. Disc Diffusion Assays. After the treatment had been applied and the inoculated plates were allowed to grow for 24 hours, the acetone extract and ethanol extract of $U$. ghattensis were showing activity against Staphylococcus aureus, Bacillus cereus, and Pseudomonas aeruginosa while no activity was found against Streptococcus faecalis, Escherichia coli, and Salmonella typhimurium.

Both concentrations of methanol extract $(0.1 \mathrm{mg} / \mathrm{mL}$ and $0.2 \mathrm{mg} / \mathrm{mL}$ ) were showing activity against all the grampositive bacteria and one gram-negative bacteria. No activity was recorded against Escherichia coli, Salmonella typhimurium. The acetone extract inhibited growth of $B$. cereus with a mean zone of $23.9 \pm 1.1 \mathrm{~mm}(0.2 \mathrm{mg} / \mathrm{mL}$ conc.) while ethanol extract of the lichen had the greatest effect on plates inoculated with Bacillus cereus with a mean zone of inhibition of $29.8 \pm 0.6 \mathrm{~mm}$ at $0.2 \mathrm{mg} / \mathrm{mL}$ concentration. The acetone and methanol extract were showing equal inhibitory effect on $S$. aureus with a mean zone of inhibition $24.6 \pm 0.5 \mathrm{~mm}$ and $24.7 \pm 0.4 \mathrm{~mm}$ at $0.2 \mathrm{mg} / \mathrm{mL}$ concentration, respectively.

The methanol extract showed poor activity against $S$. faecalis with a zone of inhibition $8.3 \pm 0.5 \mathrm{~mm}$ at a concentration of $0.1 \mathrm{mg} / \mathrm{mL}$ while the concentration $0.2 \mathrm{mg} / \mathrm{mL}$ was showing a zone of inhibition of $13.5 \pm 0.8 \mathrm{~mm}$. Ethanol extract showed greater effect on $P$. aeruginosa with a zone of inhibition of $12.3 \pm 0.5 \mathrm{~mm}$ at a concentration of $0.2 \mathrm{mg} / \mathrm{mL}$ in comparison to acetone $(8.4 \pm 0.6 \mathrm{~mm}$ dia. Zone $)$ methanolic extract $(8.7 \pm 0.4 \mathrm{~mm})$. Although the extracts were not as effective as the commercial antibiotics Gentamicin and Ceftriaxone, they have potent antibacterial activity (Table 1).

3.2. Minimum Inhibitory Concentration. The MIC values of the extract related to the tested bacterial strains varied between 25 and $3.125 \mu \mathrm{g} / \mathrm{mL}$ in case of gram-positive bacteria. The measured MIC value for the extract against Staphylococcus aureus was $6.25 \mu \mathrm{g} / \mathrm{mL}$ while the MIC value against Bacillus cereus was found to be $3.125 \mu \mathrm{g} / \mathrm{mL}$. Streptococcus faecalis was also showing $25 \mu \mathrm{g} / \mathrm{mL}$ MIC value. Against Pseudomonas aeruginosa, the MIC value noted was $200 \mu \mathrm{g} / \mathrm{mL}$. Positive control was showing growth of bacteria and negative control was clear and not showing any growth of bacteria (Table 2).

\section{Discussion}

The intensity of the antimicrobial effect depended on the type of extract, its concentration, and the tested microorganisms. The tested concentrations of all the three extracts were showing activity against all bacteria except $S$. faecalis, for which only methanol extract was showing trace activity. Against $P$.
TABLE 2: Results of Minimum Inhibitory Concentration (MIC) of extracts of Usnea ghattensis against tested microorganisms.

\begin{tabular}{lcc}
\hline $\begin{array}{l}\text { Serial } \\
\text { number }\end{array}$ & Bacterial pathogen & $\begin{array}{l}\text { Usnea ghattensis } \\
(\mathrm{MIC} \text { in } \mu \mathrm{g} / \mathrm{mL})\end{array}$ \\
\hline$(1)$ & Staphylococcus aureus & 6.25 \\
$(2)$ & Streptococcus faecalis & 25 \\
$(3)$ & Bacillus cereus & 3.125 \\
$(4)$ & Escherichia coli & NA \\
$(5)$ & Pseudomonas aeruginosa & 200 \\
$(6)$ & Salmonella typhimurium & NA \\
\hline
\end{tabular}

NA: no activity.

aeruginosa, $0.2 \mathrm{mg} / \mathrm{mL}$ concentration was showing activity while the concentration $0.1 \mathrm{mg} / \mathrm{mL}$ was ineffective.

Acetone and methanol extract was showing almost equal activity against S.aureus whereas ethanol extract was found to be more effective against $B$. cereus and $P$. aeruginosa. The reason for different sensitivity of bacteria can be found in different transparency of the cell wall [22]. The cell wall of the gram-positive bacteria consists of peptidoglycan (mureins) and teichoic acids; the cell wall of the gram-negative cells consists of lipopolysaccharides and lipoproteins [23, 24]. Most of the Parmelloid lichens exhibit strong antimicrobial activity [25-27].

According to Burkholder et al. [28], Rowe et al. [29], and Silva et al. [30], the lichens inhibit mostly gram-positive bacteria, but it is of great interest to note that the extracts of $U$. ghattensis inhibited the growth of both gram-positive bacteria and one gram-negative bacteria in the present study.

U. ghattensis showed that MIC values were varying between 25 and $3.125 \mu \mathrm{g} / \mathrm{mL}$. Similar to other Usnea species, U. ghattensis also showed equal MIC values [31].

Lichens and their metabolites have manifold biological activity: antiviral, antibiotic, enzyme inhibitory, and allergenic. Behera et al. [32] reported that the acetone, methanol, and light petroleum extracts of lichen were effective against Bacillus licheniformis, B. megaterium, and S. aureus. Karagoz et al. [33] reported antibacterial activity of aqueous and ethanolic extracts lichens like Lecanora muralis, Peltigera polydactyla, Ramalina farinacea, and Xanthoria elegans.

\section{Conclusion}

The acetone, methanol, and ethanol extracts of $U$. ghattensis have a potential towards antibacterial activity. The obtained results showed that the tested lichen extracts showed a significant antimicrobial activity relative to the tested bacteria, which could be of significance in human therapy, animal, and plant diseases. Further investigations on the antibacterial activity as well as the economical and fast isolation of the metabolite from the lichen are needed. Consequently, the antibacterial effect of plants tested can be explained with new studies by using different solvents for extraction and other bacteria accurately. 


\section{Ethical Approval}

An approval was obtained by the authors from Research Ethical Committee of Sanjay Gandhi Postgraduate Institute of Medical Sciences (SGPGIMS).

\section{Conflict of Interests}

The authors declare that they have no conflict of interests.

\section{Acknowledgments}

The authors are thankful to the Director of National Botanical Research Institute (CSIR), Lucknow, and Head of the Department of Microbiology, Sanjay Gandhi Postgraduate Institute of Medical Sciences (SGPGI), Lucknow, for providing necessary lab facilities.

\section{References}

[1] V. Ahmadijan, The Lichen Symbiosis, John Wiley \& Sons, New York, NY, USA, 1993.

[2] R. Hegnauer, Chemotaxonomy der Pflanzen. Band 1: Thallophyten, Bryophyten, Pteridophyten und Gymnospermen, Birkhaüser, Basel-Stuttgart, 1962.

[3] A. Jezierski, E. Bylinska, and M. R. D. Seaward, "Electron paramagnetic resonance (EPR) investigations of lichens-1: effects of air pollution," Atmospheric Environment, vol. 33, no. 28, pp. 4629-4635, 1999.

[4] G. H. Denton and W. Karlen, "Lichenometry: its application to Holocene moraine studies in Southern Alaska and Swedish Lapland," Arctic and Alpine Research, vol. 5, pp. 347-372, 1973.

[5] K. O. Vartia, "The Lichens," in Antibiotics in Lichens, V. Ahmadjian and M. E. Hale, Eds., pp. 547-561, Academic Press, New York, NY, USA, 1973.

[6] L. A. Mitscher, S. Drake, S. R. Gollapudi, and S. K. Okwute, "A modern look at folkloric use of anti-infective agents," Journal of Natural Products, vol. 50, no. 6, pp. 1025-1040, 1987.

[7] K. Ingolfsdottir, M. A. Hjalmarsdottir, A. Sigurdsson, G. A. Gudjonsdottir, A. Brynjolfsdottir, and O. Steingrimsson, "In vitro susceptibility of Helicobacter pylori to protolichesterinic acid from the lichen Cetraria islandica," Antimicrobial Agents and Chemotherapy, vol. 41, no. 1, pp. 215-217, 1997.

[8] K. Hostettman and J. L. Wolfender, "The search for biologically active secondary metabolites," Pesticide Science, vol. 51, pp. 471482, 1997.

[9] I. Karaman, F. Sanin, M. Gulluce, H. Ogütcü, M. Sengul, and A. Adiguzel, "Antimicrobial activity of aqueous and methanol extracts of Juniperus oxycedrusL," Journal of Ethnopharmacology, vol. 85, pp. 231-235, 2003.

[10] K. Molnár and E. Farkas, "Current results on biological activities of lichen secondary metabolites: a review," Zeitschrift fur Naturforschung C, vol. 65, no. 3-4, pp. 157-173, 2010.

[11] S. Huneck, "The significance of lichens and their metabolites," Naturwissenschaften, vol. 86, no. 12, pp. 559-570, 1999.

[12] N. T. Manojlovic, S. Solujic, and S. Sukdolak, "Antimicrobial activity of an extract and anthraquinones from caloplaca schaereri," Lichenologist, vol. 34, no. 1, pp. 83-85, 2002.

[13] N. T. Manojlović, P. Vasiljević, M. Jusković, S. Najman, S. Janković, and A. Milenković-Andjelković, "HPLC analysis and cytotoxic potential of extracts from the lichen, Thamnolia vermicularis var. subuliformis," Journal of Medicinal Plant Research, vol. 4, no. 9, pp. 817-823, 2010.

[14] N. T. Manojlovic, P. J. Vasiljevic, and Z. S. Marković, "Antimicrobial activity of extracts and various fractions of chloroform extract from the lichen Laurera benguelensis," Journal of Biological Research, vol. 13, pp. 27-34, 2010.

[15] V. Shukla, G. P. Joshi, and M. S. M. Rawat, "Lichens as a potential natural source of bioactive compounds: a review," Phytochemistry Reviews, vol. 9, no. 2, pp. 303-314, 2010.

[16] N. Toma, L. Ghetea, R. Nitu, and D. I. Corol, "Progress and perspectives in the biotechnology of lichens," Romanian Biotechnological Letters, vol. 6, pp. 1-15, 2001.

[17] R. W. Bauer, M. D. K. Kirby, J. C. Sherris, and M. Turck, "Antibiotic susceptibility testing by standard single disc diffusion method," American Journal of Clinical Pathology, vol. 45, pp. 493-496, 1966.

[18] NCCLS, Methods For Dilution Antimicrobial Susceptibility Tests For Bacteria That Grow Aerobically, Approved Standard, 2nd edn edition, 1992.

[19] S. C. Sati and S. Joshi, "Antibacterial activity of the Himalayanlichen Parmotrema nilgherrenseextracts," British Microbiology Research Journal, vol. 1, no. 2, pp. 26-32, 2011.

[20] O. J. Owolabi, E. K. I. Omogbai, and O. Obasuyi, "Antifungaland antibacterial activities of the ethanolic and aqueous extractof Kigelia africana(Bignoniaceae) stem bark," African Journal of Biotechnology, vol. 6, no. 14, pp. 1677-1680, 2007.

[21] NCCLS, PerFormance Standards For Antimicrobial Susceptibility Testing. Twelfth inFormational Supplement, Fort Wayne, Ind, USA, 2002.

[22] Y. Yang and E. J. Anderson, "Antimicrobial activity of a porcine myeloperoxidase against plant pathogenic bacteria and fungi," Journal of Applied Microbiology, vol. 86, no. 2, pp. 211-220, 1999.

[23] P. Hugenholtz, "Exploring prokaryotic diversity in the genomicera," Genome Biology, vol. 3, no. 2, pp. 1-3, 2002.

[24] J. Van Heijenoort, "Formation of the glycan chains in thesynthesis of bacterial peptidoglycan," Glycobiology, vol. 11, no. 3, pp. 25R-36R, 2001.

[25] M. Gulluce, A. Aslan, M. Sokmen et al., "Screening the antioxidant and antimicrobial properties of the lichens Parmelia saxatilis, Platismatia glauca, Ramalina pollinaria, Ramalina polymorpha and Umbilicaria nylanderiana," Phytomedicine, vol. 13, no. 7, pp. 515-521, 2006.

[26] M. Candan, M. Yilmaz, T. Tay, M. Erdem, and A. O. Turk, "Antimicrobial activity of extracts of the lichen Parmelia sulcata and its salazinic acid constituent," Zeitschrift Fur Naturforschung C, vol. 62, no. 7-8, pp. 619-621, 2007.

[27] B. Rankovic, M. Misic, and S. Sukdolak, "Antimicrobial activity of extracts of the lichens Cladonia furcata, Parmelia caperata, Parmelia pertusa, Hypogymnia physodes and Umbilicaria polyphylla," British Journal of Biomedical Science, vol. 64, no. 4, pp. 143-148, 2007.

[28] P. R. Burkholder, A. W. Evans, I. McVeigh, and H. K. Thornton, "Antibiotic activity of lichens," Proceedings of the National Academy of Sciences of the United States of America, vol. 30, pp. 250-255, 1944

[29] J. G. Rowe, M. T. Saenz, and M. D. Garcia, "Contribution a a'le tudedel' activiteantibacterienne de queques lichens du sudde l'Espagne," Pharmaceutical Francaise, vol. 47, pp. 89-94, 1989.

[30] D. A. Silva, J. Oliveira, J. E. Maileite, M. Q. Paulo, and L. X. Filho, "Antimicrobial activity of Brazilian lichens," Biological Society Broteriana, vol. 59, pp. 87-96, 1986. 
[31] I. T. Madamombe and A. J. Afolayan, "Evaluation of antimicrobial activity of extracts from South African Usnea barbata," Pharmaceutical Biology, vol. 41, no. 3, pp. 199-202, 2003.

[32] B. C. Behera, N. Verma, A. Sonone, and U. Makhija, "Antioxidantand antibacterial activities of lichen Usnea ghattensis in vitro," Biotechnology Letters, vol. 27, no. 14, pp. 991-995, 2005.

[33] A. Karagoz, N. Dogruoz, Z. Zeybek, and A. Aslan, "Antibacterial activity of some lichen extracts," Journal of Medicinal Plant Research, vol. 3, no. 12, pp. 1034-1039, 2009. 


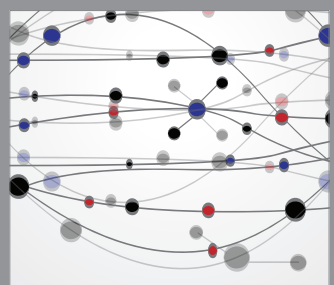

The Scientific World Journal
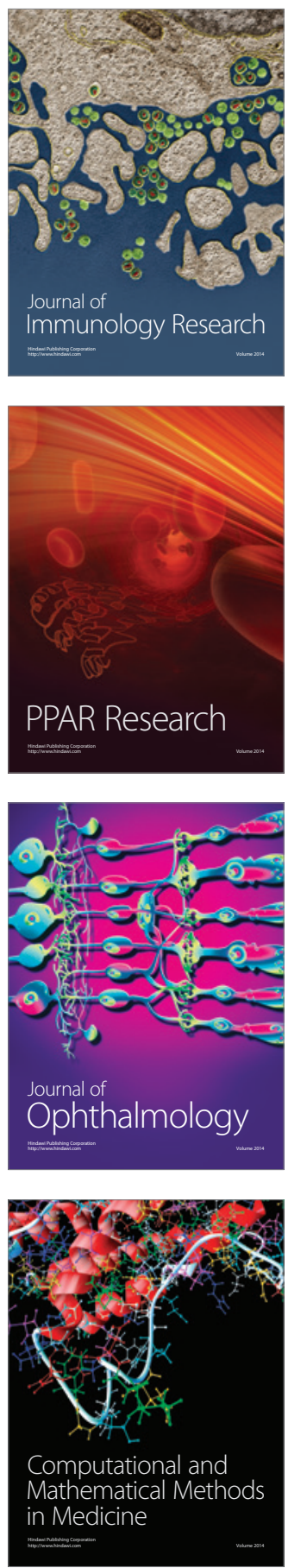

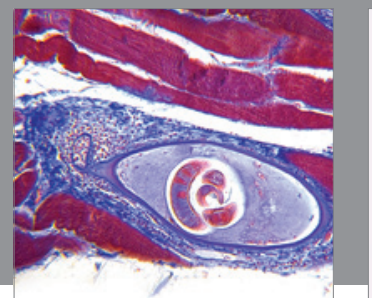

Gastroenterology

Research and Practice
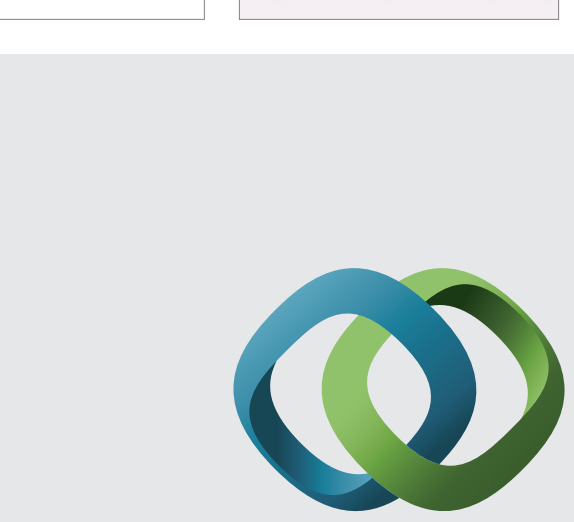

\section{Hindawi}

Submit your manuscripts at

http://www.hindawi.com
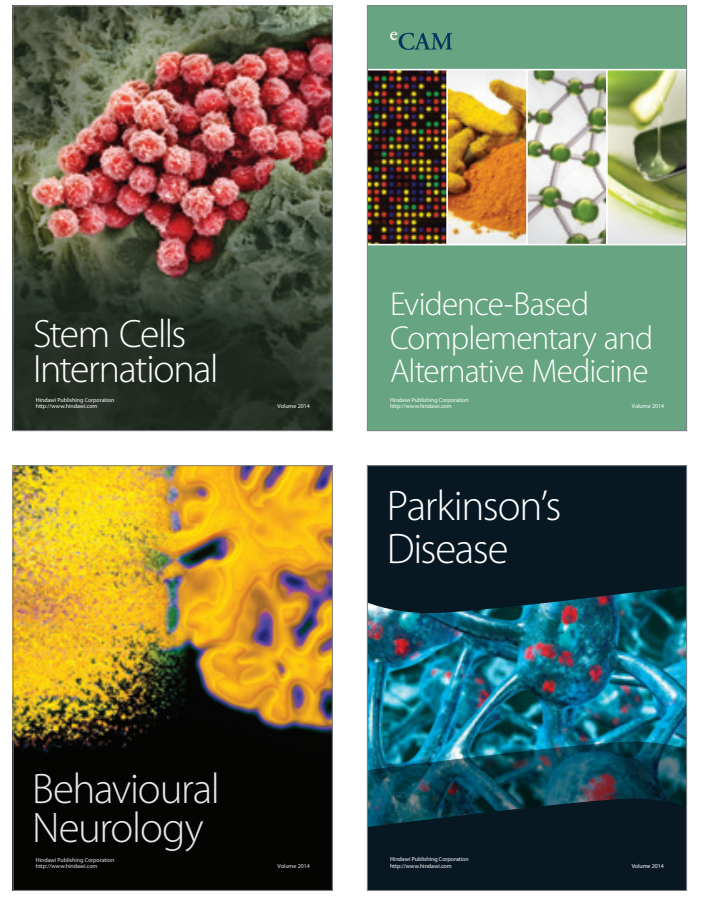
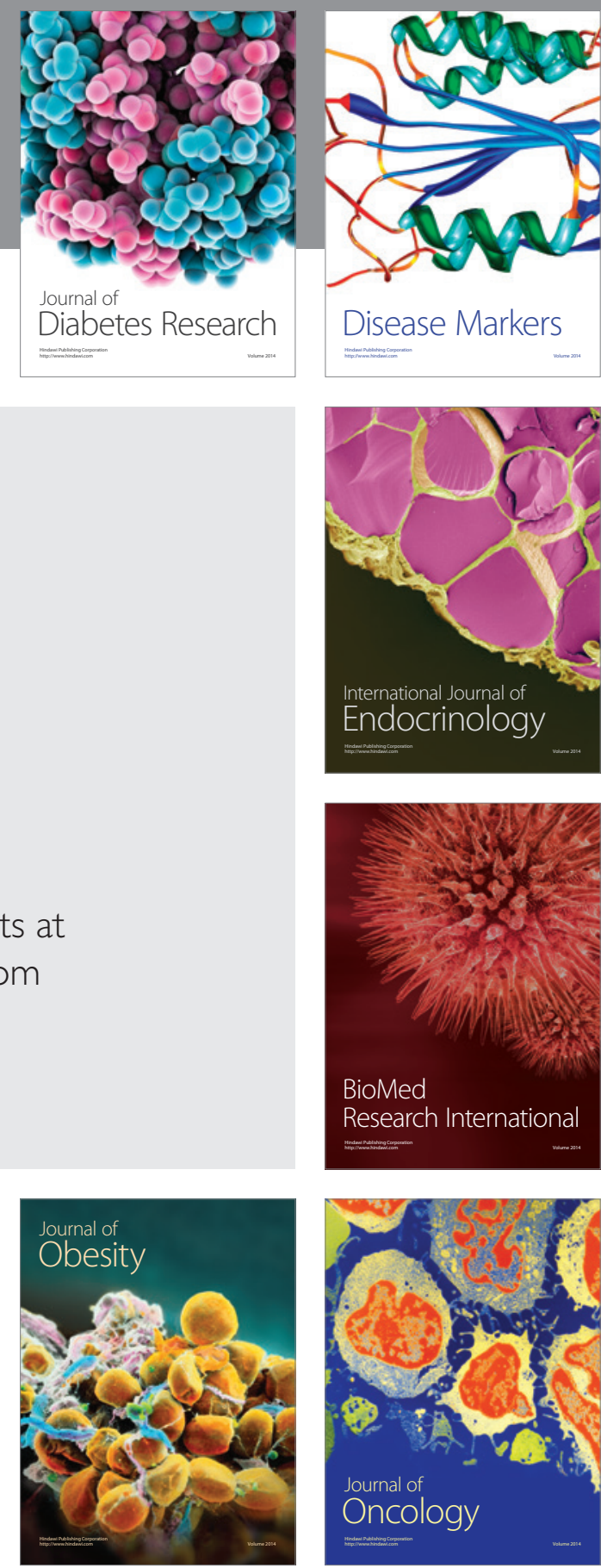

Disease Markers
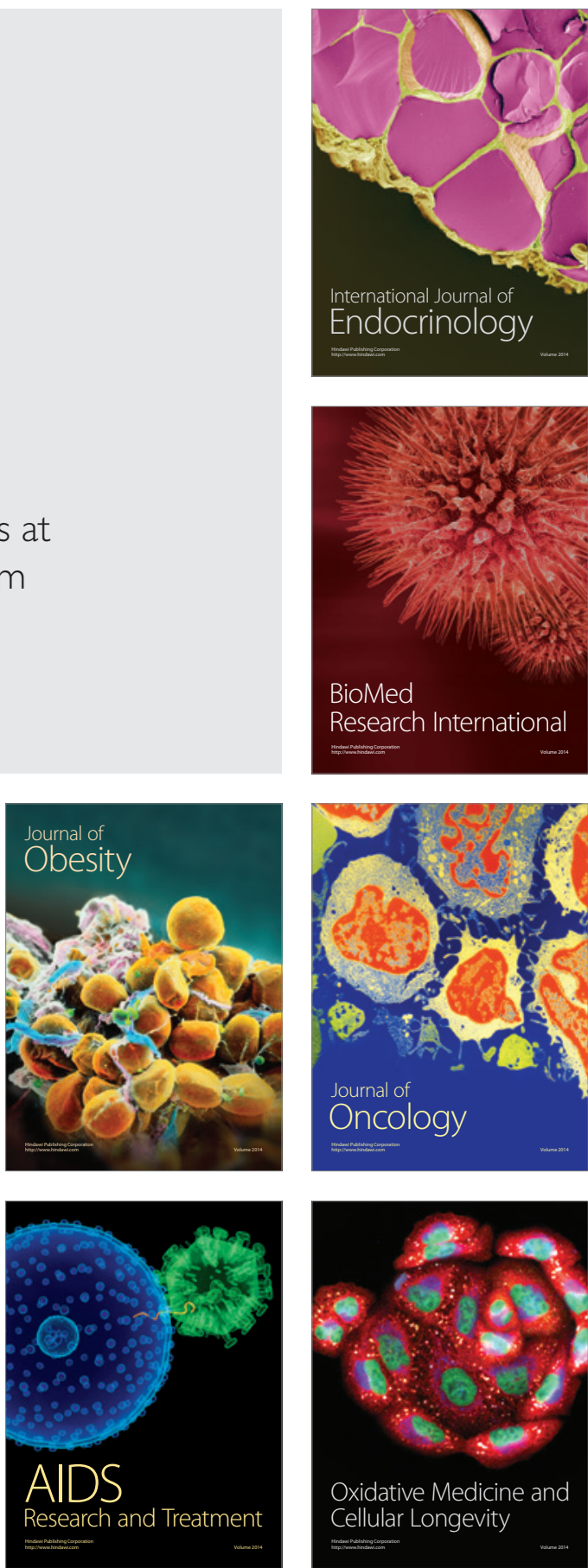